\title{
The European continental crust through detrital minerals
}

\author{
PAULA CASTILLO ${ }^{1}$, HEINRICH BAHLBURG ${ }^{1}$, JASPER \\ BERNDT $^{1}$, DAVID M CHEW ${ }^{2}$ AND MARK FANNING ${ }^{3}$ \\ ${ }^{1}$ University of Münster \\ ${ }^{2}$ Trinity College Dublin \\ ${ }^{3}$ The Australian National University \\ Presenting Author: paula.castillo@uni-muenster.de
}

To analyse the evolution of the continental crust one requires a representative sample set of crustal materials, such as river sediments. We collected sediments from the mouths of 15 large river systems in Europe for a diverse multi-proxy study. In a first step we present $\mathrm{U}-\mathrm{Pb}, \mathrm{Hf}$, and $\mathrm{O}$ isotope characteristics in their zircons to assess their age and the crustal evolution they reflect. Detrital zircons from European rivers yield ages ranging from Cenozoic to Archean, with several age clusters that can be linked to different orogenic cycles and the formation of supercontinents. Unexpected young zircons of 0.2-10 Ma were found in rivers draining the French Massif Central. They are juvenile and with little upper crustal contamination. Other Cenozoic detrital zircons are in the 25-40 Ma range and were found in the Seine, Rhine, Po and Danube rivers. Samples from all rivers have a main age group at 270-370 Ma, associated with the Variscan orogen, which appears to have been the largest episode of crustal reworking in Europe. Permian post-Variscan detrital zircons were found only in the Po and Glomma river basins. Those from the Po basin show significant crustal contamination, whereas the Scandinavian Permian zircons are more radiogenic and mantlelike. Other important age clusters are 400-490 Ma (especially in the Po, Danube, Rhine, Rhone, and Seine), and 540-650 Ma (particularly important in the Iberian Peninsula and France). Detrital zircons of 930-1170 Ma and 1400-1700 Ma are an important component in the Scandinavian Glomma river. They can also be found in mainland rivers draining into the Baltic and North Sea, likely due to the transport of sediments during the last glaciation. The oldest detrital zircons scatter between ca. 1800 and $3000 \mathrm{Ma}$ and are mainly found in the southern Iberian Peninsula and in the Oder, Seine, and Rhone rivers. We will also present our preliminary results on combining $\mathrm{U}-\mathrm{Pb}$ dating with trace-element fingerprinting of other robust common detrital minerals, such as rutile, apatite, and titanite. As these minerals can be formed/reset at different P-T conditions than zircon, they can be used to evaluate potential biases in the detrital zircon record. 